\title{
エンフルレン麻酔の循環動態と肝血流に関する 実験的研究
}

岡山大学医学部麻酔・蘇生学教室 (指導 : 小坂 二度見教授)

谷口正廣

(昭和62年 7 月 28 日受稿)

Key words : エンフルレン

血中エンフルレン浱度

循環動態

肝血流

\section{粕}

エンフルレンは，1963年 Ross Terrell らに より合成された揮発性麻醉薬である.エンフル レン吸入時における全身循環および肝循環動態 の研究は，1979年 Andreen と Irestedt ら ${ }^{1)} に$ より行なわれ，犬に $1 \mathrm{MAC} の \mathrm{GOE}$ 麻酔（笑 気・酸素・エンフルレン麻䣲： $\mathrm{FiO}_{2} \quad 0.3 ）$ を 行なった場合, 肝動脈血流量 (HABF) およ び門脈血流量 (PVBF) がそれぞれ対照值の $65 \%, 64 \%$ に減少し，全末梢血管抵抗 (SVR) と肝動脈血管抵抗（HAVR）が有意に減少す ると報告している. 1980年 Hughes ら ${ }^{2)}$ は, $3 \%$ NOE 麻醉（窒素・酸素・エンフルレン麻 醉: $\mathrm{FiO}_{2}$ 0.25) では $\mathrm{HABF}, \mathrm{PVBF}$ がそれ ぞれ $50 \%, 49 \%$ に滅少し, SVR とHAVRの有 意な減少を報告している．水上ら ${ }^{3)}$ は，平均動 脤圧が75～80 mmHg となるよう GOE 麻酔： $\mathrm{Fio}_{2} \quad 0.25$ 行ないHABF は60\%に減少する か，PVBFは変動が少なく麻酔終了 4 時間後 には, HABF は98\%, PVBF は94.6\%に回復 したと報告している. しかし，エンフルレンの 投与搌度に対する肺胞内浱度と血中浱度の測定 により麻酥深度を確立したもとで，経時的な全 身循環と肝循罧の変化と相関についての詳しい 研究はいまだ報告されていない.

本研究は，エンフルレン麻酔および麻酔後の
経時的な全身循環と肝循環の変化および両者の 相関を解明するために，雑種成犬を用いエンフ ルレン吸入中 2 時間および吸入中止後90分のエ ンフルレン投与浱度と血中浱度の変化における 全身循環動態，肝循環動態および腸間膜血流動 態を測定し,エンフルレン吸入渡度 $(0.7 \mathrm{MAC}$, $1 \mathrm{MAC}) に お け る$ 吸入中および吸入中止後の 全身，肝および腸間膜循環動態の変化について 総合的に検討した。

$$
\text { 方法 }
$$

実験は雑種成犬20頭（平均体重11.3kg）を使 用し, そのうち 10 頭はエンフルレン $2 \%$ 吸入群 (OE $2 \%$ 群),残りの10頭はエンフルレン $3 \%$ 吸入群 (OE $3 \%$ 群) の 2 群に分け以下の実験 を行なった。

実験は，塩酸ヶタミン $50 \mathrm{mg}$ および硫酸アトロ ピン $0.5 \mathrm{mg}$ 筋注後，サイアミラールナトリウ 厶 $10 \mathrm{mg} / \mathrm{kg}$ と臭化パンクロニウム $4 \mathrm{mg}$ を静注し 気管内挿管を行なった，動静脈路確保および動 脈圧モニターは, 大腿動静脈切開により行なっ た. 呼吸は，半閉鎖式回路で従量式ベンチレー ター (Oxford-Ventilartor) にて, 100\%酸素 で調節呼吸を行ない, 日本光電 $\mathrm{CO}_{2}$ モニター (OIR-7101) で $\mathrm{P}_{\mathrm{A}} \mathrm{CO}_{2}$ が $40 \mathrm{~mm} \mathrm{Hg}$ となるよう に設定するとともに動脈血ガス分析 (Corning $168 \mathrm{PH} /$ blood gas analyzer) にて $\mathrm{P}_{\mathrm{a}} \mathrm{CO}_{2}$ が 


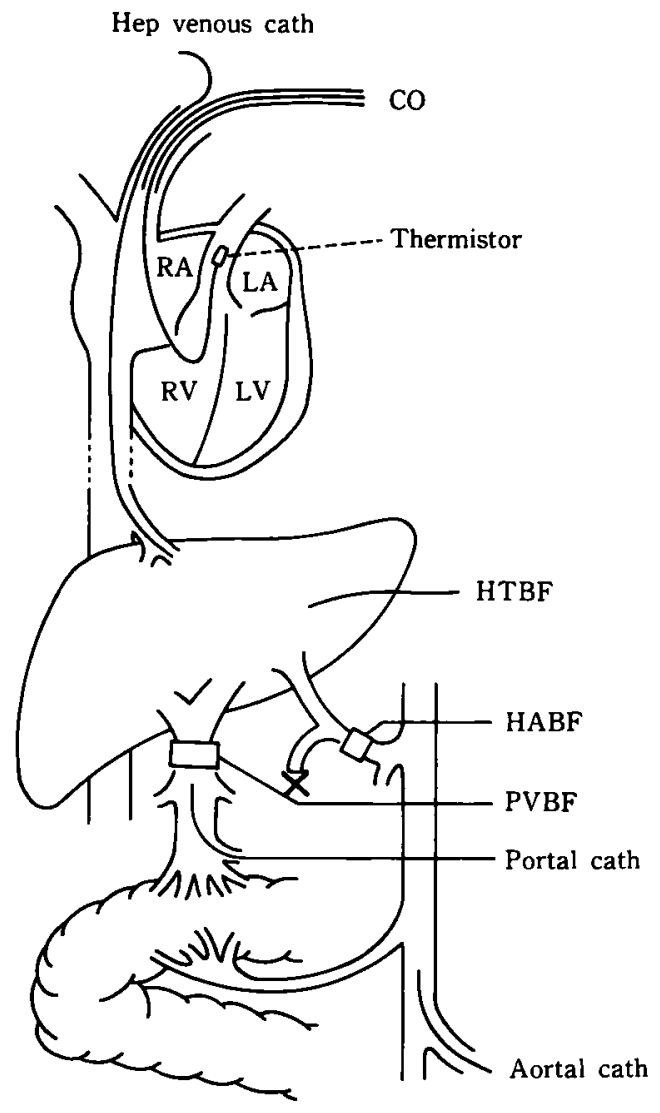

図 1 実験略図

(Thulin L, Andreen M, Irestedt L: Effect of controlled halothane anaesthesia on splanchnic blood flow and cardiac output in the dog.

Acta Anaesth Scand 19:146, 1975 より・部改変引 用)

HABF : 肝動脈血流量, PVBF : 門脈血流量, HTBF：肝組織血流量

$40 \mathrm{~mm} H$ となっていることを確認した。

肝静脈の採血および肝静脈圧測定は, 右外澒 静脈より肝静脈へカテーテルを㨉入，留置して 行なった。 心拍出量, 肺動脈圧, 肺動脈揳入圧, 右房圧は, 右外䅡静脈より，Swan-Ganz カテー テル（5Fまたは $7 \mathrm{~F} ）$ を挿入して测定した。

肝動脈および門脈の血流量測定は, 正中切開法 により開腹し胃十二指腸動脈を結禁後，肝動脈 へは径 2 $3 \mathrm{~mm}$, 門脈へは径 5 7 $\mathrm{mm}$ のプロー ベを装着して電磁流量計（日本光電製 $\mathrm{MFV}$ 1100型）にて測定した。
門脈圧は，腸間膜静脈末梢から19G，30cmの エラスター針を門脈まで抻入して測定した. 肝 組織血流量 (HTBF) は, 直径0.15 mmのプラ チナ・イリジウム電極を肝実質に刺入して水素 クリアランス式組織血流計 (Unique Medical UH Meter MHGDIC)により測定した（図 1). エンフルレン投与は，ムラコメディカル社製 Enfluwick 気化器を使用した。

肝静脈血中酸素的和度は， Radiometer $\mathrm{OSM}_{2}$, 肺胞内エンフルレン浱度は, 島津 GC-3BF 型ガスクロマトグラフを用いて測定 した，血中エンフルレン㳻度は，島津 GC-6AMP $\mathrm{r} T$ F 型ガスクロマトグラフにより 山田 ${ }^{4)}$ の方法を用いて湘定した。

輸液は，乳酸リンゲル液を右房圧が $5 \sim 6 \mathrm{~mm}$ Hgになるよう投与した。

各測定項目の対照值は，循環動態が手術侵襲 の影響から回復するのを待って，2回測定し， その平均值をとった。

エンフルレン吸入は120分間行ない, 各測定 項目は, エンフルレン吸入開始後30分，60分， 90 分， 120 分および吸入中止後 30 分， 60 分， 90 分の各時点において測定した。

肝重量は, 実験終了後肝切除を行ない測定し, 同時に肝静脈内にカテーテルが留置されている ことを確認した。

心係数 (CI), 全末梢血管抵抗 (SVR), 肝 動脈血管抵抗 (HAVR)，腸間膜血管抵抗 (MVR) は下式により算出した.

- CI : 心拍出量/体表面積5) $\mathrm{L} / \mathrm{min}$

-SVR： \{(平均動脈圧一右房圧) / 心拍出量\} $\times 80 \mathrm{dyn} \cdot \mathrm{sec} \cdot \mathrm{cm}^{-5}$

- HAVR：（平均動脈圧一肝静脈圧）/肝動 脈血流量 $\times 80 \mathrm{dyn} \cdot \mathrm{sec} \cdot \mathrm{cm}^{-5}$

- MVR：\{(平均動脈圧一門脈圧)/門脈血流量\} $\times 80 \mathrm{dyn} \cdot \mathrm{sec} \cdot \mathrm{cm}^{-5}$

循環動態の変化は，すべて対照値に対する変 化率で表示し, 統計学的処理では, OE $2 \%$ 群 と OE $3 \%$ 群の有意差の検討は Student-t test を用い，対照值と測定值との有意差の検討は Paird-t testを用い， $\mathrm{p}<0.05$ 以下を有意差あり とした. 
表 1 エンフルレン吸入時および吸入中止後の各種バラメーターの測定結果

\begin{tabular}{|c|c|c|c|c|c|c|c|c|c|}
\hline & & \multirow[b]{2}{*}{ Control } & \multicolumn{4}{|c|}{ Enflurane inhalation } & \multicolumn{3}{|c|}{ Post inhalation } \\
\hline & & & 30 & 60 & 90 & 120 & 30 & 60 & $90(\mathrm{~min})$ \\
\hline $\begin{array}{c}\text { AEC } \\
\%\end{array}$ & $\begin{array}{l}\text { OE } 2 \% \\
\text { OE } 3 \%\end{array}$ & & $\begin{array}{l}1.30 \pm 0.08 \\
2.34 \pm 0.09 \\
p<0.01\end{array}$ & $\begin{array}{c}1.45 \pm 0.07 \\
2.38 \pm 0.07 \\
p<0.01\end{array}$ & $\begin{array}{c}1.54 \pm 0.06 \\
2.39 \pm 0.06 \\
p<0.01\end{array}$ & $\begin{array}{c}1.60 \pm 0.04 \\
2.42 \pm 0.06 \\
p<0.01\end{array}$ & $\begin{array}{c}0.22 \pm 0.02 \\
0.51 \pm 0.04 \\
p<0.01\end{array}$ & $\begin{array}{c}0.12 \pm 0.01 \\
0.25 \pm 0.02 \\
p<0.01\end{array}$ & $\begin{array}{c}0.05 \pm 0.01 \\
0.12 \pm 0.01 \\
p<0.01\end{array}$ \\
\hline $\begin{array}{l}\text { ABEC } \\
\mathrm{mg} / \mathrm{d}\end{array}$ & $\begin{array}{l}\text { OE } 2 \% \\
\text { OE } 3 \%\end{array}$ & & $\begin{array}{r}26.1 \pm 4.6 \\
42.2 \pm 6.1 \\
p<0.01\end{array}$ & $\begin{array}{c}28.7 \pm 2.1 \\
46.7 \pm 6.6 \\
p<0.01)\end{array}$ & $\begin{array}{r}29.5 \pm 1.8 \\
48.6 \pm 6.1 \\
p<0.01\end{array}$ & $\begin{array}{r}31.1 \pm 2.2 \\
50.3 \pm 6.4 \\
p<0.01\end{array}$ & $\begin{array}{r}8.3 \pm 2.2 \\
15.5 \pm 3.3 \\
p<0.01\end{array}$ & $\begin{array}{l}5.1 \pm 0.6 \\
9.8 \pm 1.7 \\
p<0.01\end{array}$ & $\begin{array}{l}3.6 \pm 0.4 \\
6.8 \pm 1.0 \\
p<0.01\end{array}$ \\
\hline HR & $\begin{array}{l}\text { OE } 2 \% \\
\text { OE } 3 \%\end{array}$ & $\begin{array}{l}196.8 \pm 17.0^{\text {a) }} \\
200.4 \pm 14.2 \\
\text { NS }\end{array}$ & $\begin{array}{c}-31.4 \pm 8.8(H) \\
-47.1 \pm 7.1 \\
p<0.01\end{array}$ & $\begin{array}{c}-36.9 \pm 6.9(H) \\
-51.9 \pm 5.4(H) \\
p<0.01\end{array}$ & $\begin{array}{c}-38.4 \pm 7.4(H) \\
-54.1 \pm 5.1(H) \\
p<0.01\end{array}$ & $\begin{array}{c}-39.3 \pm 7.5(H) \\
-54.6 \pm 4.4(H) \\
p<0.01\end{array}$ & $\begin{array}{c}-3.1 \pm 9.6(-) \\
-29.6 \pm 14.8(t) \\
p<0.01\end{array}$ & $\begin{array}{l}1.4 \pm 10.71-1 \\
-6.8 \pm 10.9-1 \\
\text { NS }\end{array}$ & $\begin{array}{c}-0.3 \pm 9.9(-) \\
-2.8 \pm 9.5(-) \\
\text { NS }\end{array}$ \\
\hline MAP & $\begin{array}{l}\text { OE } 2 \% \\
\text { OE } 3 \%\end{array}$ & $\begin{array}{l}139.3 \pm 17.6^{b)} \\
141.1 \pm 14.6 \\
\text { NS }\end{array}$ & $\begin{array}{c}-33.2 \pm 11.6(t) \\
-60.7 \pm 7.8(H) \\
p<0.01\end{array}$ & $\begin{array}{c}-43.2 \pm 6.5(t) \\
-62.4 \pm 8.9(t) \\
p<0.01\end{array}$ & $\begin{array}{c}-42.1 \pm 5.8(H) \\
-63.2 \pm 9.0(H) \\
p<0.01\end{array}$ & $\begin{array}{c}-39.9 \pm 6.0(\mathrm{H}) \\
-62.0 \pm 9.0(\mathrm{H}) \\
p<0.01\end{array}$ & $\begin{array}{l}6.5 \pm 8.7(+) \\
-6.6 \pm 14.1(-) \\
\text { NS }\end{array}$ & $\begin{array}{l}11.0 \pm 11.0+1 \\
7.5 \pm 10.51+1 \\
\text { NS }\end{array}$ & $\begin{array}{l}7.6 \pm 8.5(+) \\
13.7 \pm 11.5(+) \\
\text { NS }\end{array}$ \\
\hline $\mathrm{CI}$ & $\begin{array}{l}\text { OE } 2 \% \\
\text { OE } 3 \%\end{array}$ & $\begin{array}{l}5.23 \pm 0.73^{c)} \\
5.55 \pm 0.91 \\
\quad \text { NS }\end{array}$ & $\mid \begin{array}{c}-41.7 \pm 7.3(t) \\
-40.1 \pm 13.7(t) \\
\text { NS }\end{array}$ & $\begin{array}{c}-37.5 \pm 6.5 \\
-48.1 \pm 11.9(*) \\
\text { NS }\end{array}$ & $\begin{array}{c}-44.1 \pm 6.7(H) \\
-52.4 \pm 5.5(H) \\
p<0.05\end{array}$ & $\begin{array}{c}-47.5 \pm 4.4(H) \\
-55.5 \pm 4.2(H) \\
p<0.05\end{array}$ & $\begin{array}{c}-30.2 \pm 19.5(t) \\
-28.6 \pm 21.2(t) \\
\text { NS }\end{array}$ & $\begin{array}{c}-30.6 \pm 20.7(H) \\
-28.8 \pm 11.8 *) \\
\text { NS }\end{array}$ & $\begin{array}{c}-36.2 \pm 14.7(t+1) \\
-32.2 \pm 7.5(t) \\
\text { NS }\end{array}$ \\
\hline HABF & $\begin{array}{l}\text { OE } 2 \% \\
\text { OE } 3 \%\end{array}$ & $\begin{array}{l}32.5 \pm 8.1 \text { d) } \\
32.5 \pm 5.4 \\
\text { NS }\end{array}$ & $\begin{array}{c}-5.4 \pm 32.6(-) \\
-9.7 \pm 17.0(-) \\
\text { NS }\end{array}$ & $\begin{array}{c}-2.0 \pm 22.3(-1) \\
-23.7 \pm 13.8(+) \\
\text { NS }\end{array}$ & $\begin{array}{c}-2.0 \pm 19.6(-) \\
-37.0 \pm 13.1(+1) \\
p<0.01\end{array}$ & $\begin{array}{c}-7.4 \pm 14.7(-) \\
-39.4 \pm 13.8(\mathrm{H}) \\
p<0.01\end{array}$ & $\begin{array}{c}21.2 \pm 45.0(-) \\
-20.3 \pm 28.1(-) \\
\text { NS }\end{array}$ & $\begin{array}{c}33.7 \pm 34.8-1 \\
-8.2 \pm 33.11-1 \\
p<0.05\end{array}$ & $\begin{aligned} 22.2 \pm 40.9-1 \\
-24.3 \pm 27.8(-) \\
p<0.05\end{aligned}$ \\
\hline PVBF & $\begin{array}{l}\text { OE } 2 \% \\
\text { OE } 3 \%\end{array}$ & $\begin{array}{c}103.7 \pm 14.4^{\text {e) }} \\
100.4 \pm 24.4 \\
\text { NS }\end{array}$ & $\left\{\begin{array}{c}-23.0 \pm 15.5(H) \\
-21.8 \pm 19.8(H) \\
\text { NS }\end{array}\right.$ & $\begin{array}{c}-34.2 \pm 9.2(t) \\
-37.9 \pm 15.4(t) \\
\text { NS }\end{array}$ & $\begin{array}{c}-38.7 \pm 6.6(H) \\
-44.5 \pm 13.6(H) \\
\text { NS }\end{array}$ & $\begin{array}{c}-37.7 \pm 8.2(H) \\
-50.4 \pm 14.1(H) \\
\text { NS }\end{array}$ & $\begin{array}{c}-22.4 \pm 13.0(t) \\
-29.0 \pm 16.9(t) \\
\text { NS }\end{array}$ & $\begin{array}{c}-24.6 \pm 9.5(H) \\
-37.2 \pm 17.9(H) \\
\text { NS }\end{array}$ & $\begin{array}{c}-30.6 \pm 1.5(H) \\
-39.0 \pm 16.8(t) \\
\text { NS }\end{array}$ \\
\hline THBF & $\begin{array}{l}\text { OE } 2 \% \\
\text { OE } 3 \%\end{array}$ & $\begin{array}{l}130.0 \pm 26.7 \text { f) } \\
131.9 \pm 27.9 \\
\text { NS }\end{array}$ & $\mid \begin{array}{c}-15.8 \pm 15.7(4) \\
-22.9 \pm 22.0(n) \\
\text { NS }\end{array}$ & $\begin{array}{c}-21.0 \pm 13.2(+1) \\
-37.2 \pm 11.9(+) \\
p<0.05\end{array}$ & $\begin{array}{c}-22.6 \pm 13.6(H) \\
-40.6 \pm 10.3(H) \\
p<0.05\end{array}$ & $\begin{array}{c}-27.7 \pm 13.6(+1) \\
-46.8 \pm 10.9(+1) \\
p<0.05\end{array}$ & $\begin{array}{l}-6.5 \pm 19.9-1 \\
-20.7 \pm 12.0(t) \\
\text { NS }\end{array}$ & $\begin{array}{c}-4.3 \pm 15.4(-) \\
-27.5 \pm 7.5(H) \\
\text { NS }\end{array}$ & $\begin{array}{c}-14.0 \pm 22.9(-) \\
-33.1 \pm 10.7(t) \\
\text { NS }\end{array}$ \\
\hline HTBF & $\begin{array}{l}\text { OE } 2 \% \\
\text { OE } 3 \%\end{array}$ & $\begin{array}{l}\left.59.0 \pm 12.6^{\mathrm{g}}\right) \\
54.6 \pm 7.6 \\
\text { NS }\end{array}$ & $\begin{array}{c}-16.1 \pm 9.9(4) \\
-26.3 \pm 9.1 \text { (H) } \\
p<0.01\end{array}$ & $\begin{array}{c}-13.3 \pm 12.1(+) \\
-33.8 \pm 9.9(+) \\
p<0.01\end{array}$ & $\begin{array}{c}-17.8 \pm 11.7(t) \\
-39.3 \pm 7.3(n) \\
p<0.01\end{array}$ & $\begin{array}{c}-15.0 \pm 9.7(H) \\
-44.3 \pm 6.4(H) \\
p<0.01\end{array}$ & $\begin{array}{c}18.3 \pm 22.8(+) \\
-20.9 \pm 13.6(t) \\
p<0.01\end{array}$ & $\begin{aligned} 9.6 \pm 13.8-1 \\
-17.7 \pm 12.4(t) \\
p<0.01\end{aligned}$ & $\begin{aligned}-2.0 \pm 13.1(-) \\
-23.3 \pm 9.5(H) \\
p<0.05\end{aligned}$ \\
\hline HV.SatOh & $\begin{array}{l}\text { OE } 2 \% \\
\text { OE } 3 \%\end{array}$ & $\begin{array}{l}96.1 \pm 1.4^{h)} \\
94.4 \pm 2.4 \\
\text { NS }\end{array}$ & $\begin{array}{c}-3.0 \pm 2.4(t) \\
-4.3 \pm 4.8(+) \\
\text { NS }\end{array}$ & $\begin{array}{c}-4.3 \pm 3.6(t) \\
-6.8 \pm 4.6(t) \\
\text { NS }\end{array}$ & $\begin{array}{l}-5.1 \pm 3.6(H) \\
-9.2 \pm 6.5(H) \\
\text { NS }\end{array}$ & $\begin{array}{c}-7.7 \pm 4.6(H) \\
-11.2 \pm 5.2(H) \\
\text { NS }\end{array}$ & $\begin{array}{l}-2.7 \pm 3.7(+) \\
-3.5 \pm 4.5(+) \\
\text { NS }\end{array}$ & $\begin{array}{c}-1.8 \pm 1.6(t) \\
-3.3 \pm 3.3(t) \\
\text { NS }\end{array}$ & $\begin{array}{c}-1.9 \pm 0.5(+) \\
-4.6 \pm 5.6(+) \\
\text { NS }\end{array}$ \\
\hline
\end{tabular}

循㯲系パラメーターの数値は, 対照のみ実測值を示し他は対照値を基準としたパーセント変化率を示 す。各群とも $\mathrm{n}=10 て ゙$ 数值は平均值 $\mathrm{SD}$ を示す.

AEC：肺胞内エンフルレン灌度, ABEC：動脈血中エンフルレン浱度, HR：心拍数, MAP：平均動脈圧, $\mathrm{CI}$ ：心保数, HABF：肝動脈血流量, PVBF：門脈血流量, THBF：総肝血流量, HTBF : 肝組織血流量, $\mathrm{HV}$-Sat $\mathrm{O}_{2}$ : 肝静脈酸素飽和度を示す. 各パラメーターの対照值の単位は次のa) 一 h)である，a） beat $/ \min \quad$ b) $\mathrm{mmHg} \quad$ c) $\mathrm{L} / \mathrm{min} / \mathrm{m}^{2} \quad$ d) $\left.\sim \mathrm{g}\right) \mathrm{ml} / \mathrm{min} / 100 \mathrm{~g}$ tissue $\left.\quad \mathrm{h}\right) \%$ $($ ）：有意差無 L, $(+): p<0.05,(++) ： p<0.01$ は对照值に対する比較である. NS：有意差無し, $\mathrm{p}<0.05, \mathrm{p}<0.01$ は群間比較である.

\section{菬果}

1. 肺胞内エンフルレン濃度と動脈血中エン

フルレン浱度の経時的変化

(1)肺胞内エンフルレン榐度は，表 1 および図 2 (a)のごとく，OE $2 \%$ 群は，エンフルレン吸入 開始から30分後には吸気中エンフルレン浱度の
$65 \%$ に上昇し，120分後まで漸増して $80 \%$ に達 した. OE $3 \%$ 群は吸入開始後30分後には78\% に上昇し，120分後には $81 \%$ となった。吸入中 止後には, OE $2 \%$ 群, OE $3 \%$ 群ともに速や かに隇少した。

(2)動脈血中エンフルレン濃度は，表 1 および図 2 (b)のごとくOE $2 \%$ 群はエンフルレン吸入開 
(a)

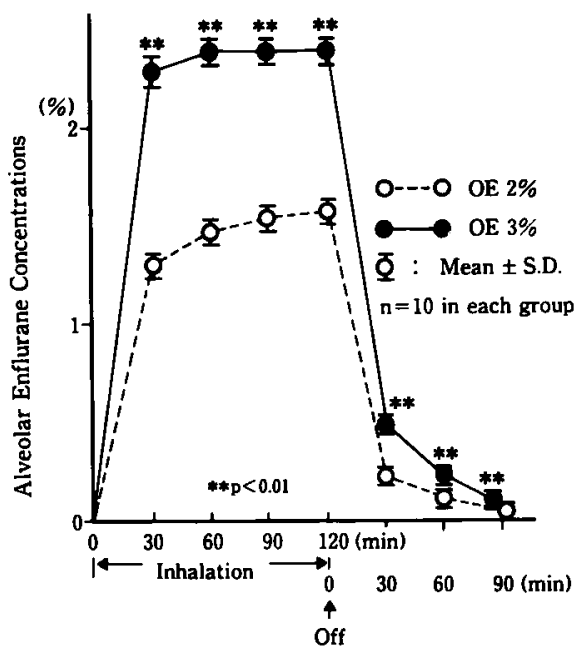

(b)

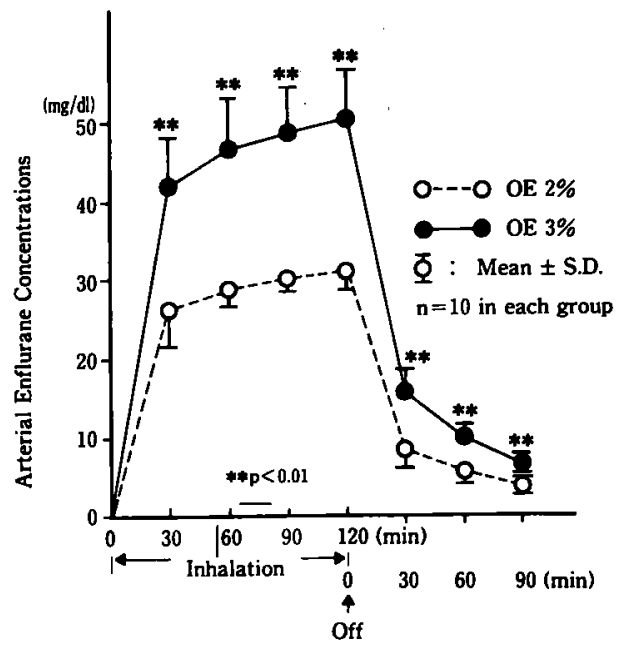

図 2 肺胞内および動脈血中エンフルレン濃度の経時的変化

(a)

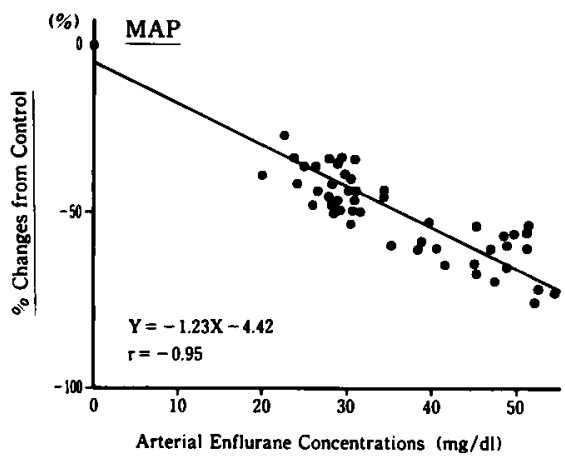

(c)

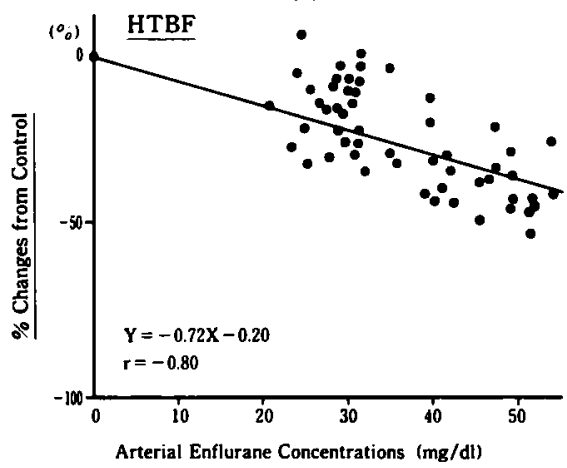

(b)

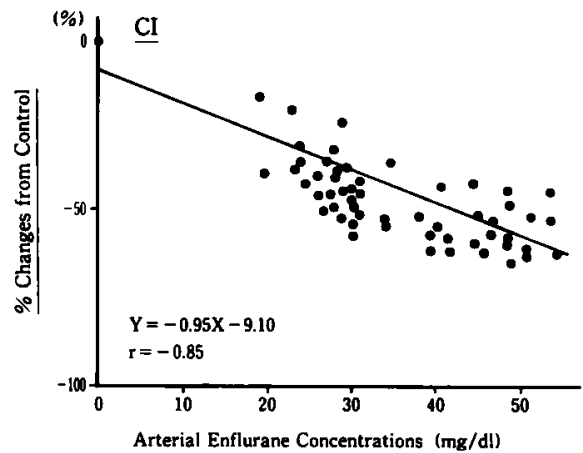

(d)

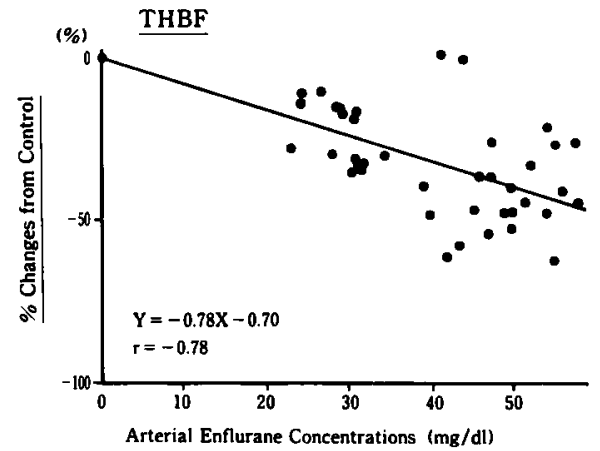

図 3 動脈血中エンフルレン渡度と平均動脈圧(MAP)，心係数(CI)，肝組織血流量 (HTBF)および総肝血流量 (THBF)の相関関保

動脈血中エンフルレン瀑度と MAP, CI, HTBF およびTHBFは，全て高い負の相関を示した。 
(a)

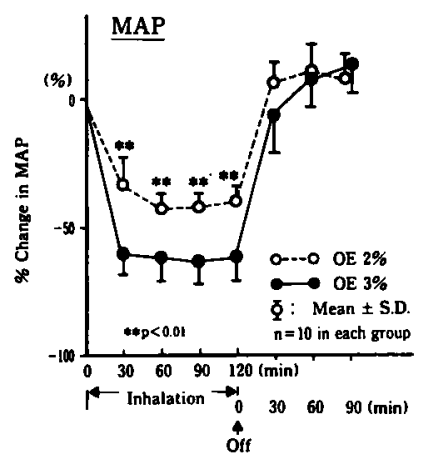

(b)

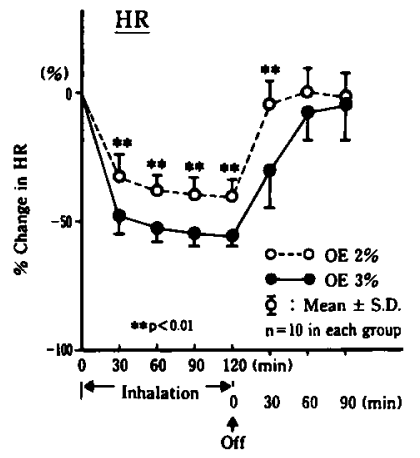

(c)

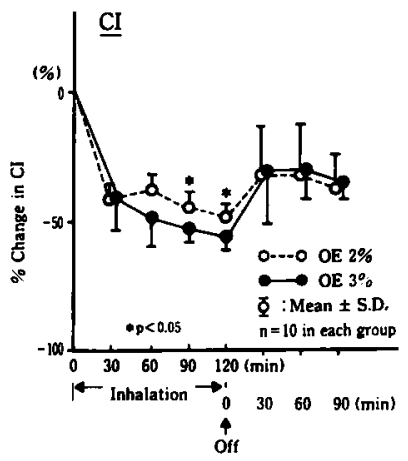

図 4 エンフルレン吸入時およひ吸入中止後の全身循環動慤の経時的変化 OE $2 \%$ 群と OE $3 \%$ 群の間では，エンフルレン吸入中 CI で差が少なくMAPで著明な差が認められた. エンフルレン吸入中止後は MAP は，速かに对照值に復するがCI の回復割合は少なかった. $\mathrm{HR}$ ：心拍数, MAP：平均動脈圧, $\mathrm{CI}$ ：心係数

始から 30 分後には $26 \mathrm{mg} / \mathrm{d} 1 ， 120$ 分後には $31 \mathrm{mg}$ $/ \mathrm{d} 1$ に達し，吸入中止 30 分後には $8 \mathrm{mg} / \mathrm{d} 1,90$ 分後には $3.6 \mathrm{mg} / \mathrm{d} 1$ と減少した. OE $3 \%$ 群は, エンフルレン吸入開始から 30 分後には $42 \mathrm{mg}$ $/ \mathrm{dl}, 120$ 分後には $50 \mathrm{mg} / \mathrm{d} 1$ となり, 吸入中止 30 後には $16 \mathrm{mg} / \mathrm{d} 1,90$ 分後には $6.8 \mathrm{mg} / \mathrm{d} 1$ となった.

2. 動脈血中エンフルレン濃度と平均動脈圧 (MAP)，心係数 ( $\mathrm{CI})$, 肝組織血流量 (HTBF) おょび総肝血流量 (THBF) の相関関係

图 3 のごとく動脈血中エンフルレン浱度と, MAP は, $\mathrm{Y}=-1.23 \mathrm{X}-4.42 \quad \mathrm{r}=-0.95$ p $<0.005$

CI は, $Y=-0.95 X-9.10 \quad r=-0.85$ $\mathrm{p}<0.005$

HTBF は, $Y=-0.72 X-0.20 \quad r=-0.80$ $\mathrm{p}<0.005$

THBF は, $Y=-0.78 X-0.70 \quad \mathrm{r}=-0.78$ $\mathrm{p}<0.005$

であり，それぞれ，高い負の相関関係が認めら れた。

3. MAP, CI および心拍数 (HR) の経時 的変化

MAPは，表 1 および図 4(a)のごとく，OE $2 \%$ 群はエンフルレン吸入30分後には，対照值 の $33 \%$ 隇少， 120 分後には $40 \%$ 減少した. エン
フルレン吸入中止後は, 対照值に対し有意に增 加した。 OE $3 \%$ 群は，エンフルレン吸入30分 後には, 対照値の $60 \%$ 減少し, 以後 120 分後ま で著変を認めなかった，吸入中止 60 分以後，対 照值に対し有意に增加した。

HR は，表 1 および図 4 (b)のごとく OE $2 \%$ 群はエンフルレン吸入30分後には対照值の $31 \%$ 減少し，120分後には $39 \%$ 減少した。吸入中止 30分後には速やかに対照値に復した，OE 3\% 群はエンフルレン吸入開始 30 分後には対照值 の $47 \% ， 120$ 分後には55\%減少した。吸入中止 60分以後, 対照値に復した.

$\mathrm{CI}$ は，表 1 および図 4 (c)のごとく OE $2 \%$ 群はエンフルレン吸入中, 対照值の $40 \sim 45 \%$ の 減少を示し，吸入中止後60分まで対照値の $30 \%$ 减少，吸入中止後90分で36\%の減少を認めた。 OE $3 \%$ 群は，エンフルレン吸入開始 30 分後に は対照值の $40 \%$ 減少， 120 分後には $55 \%$ 減少し た。吸入中止後 90 分まで対照値の $30 \%$ の減少を 認めた。

4. 肝組織血流量 (HTBF), 肝動脈血流量 (HABF)，門脈血流量(PVBF)，およ び絵肝血流量 (THBF) の経時的变化

HTBF は, 表 1 および図 5 (a)のごとく OE $2 \%$ 群はエンフルレン吸入中, 対照值の13 $17 \%$ の減少を認めた. 吸入中止 30 分後には対照 
(b)

(a)

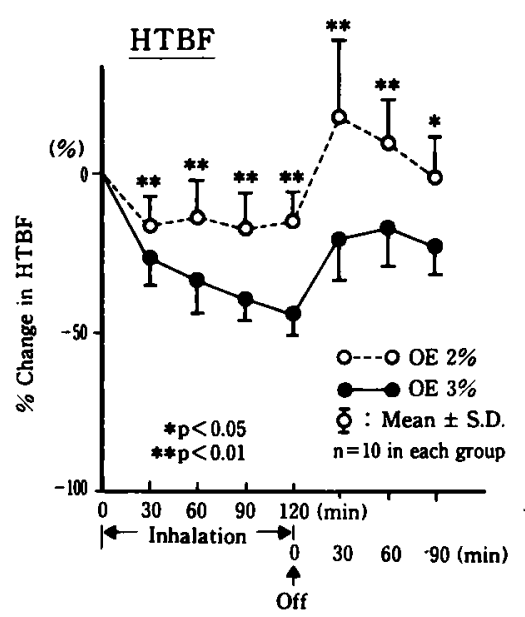

(c)

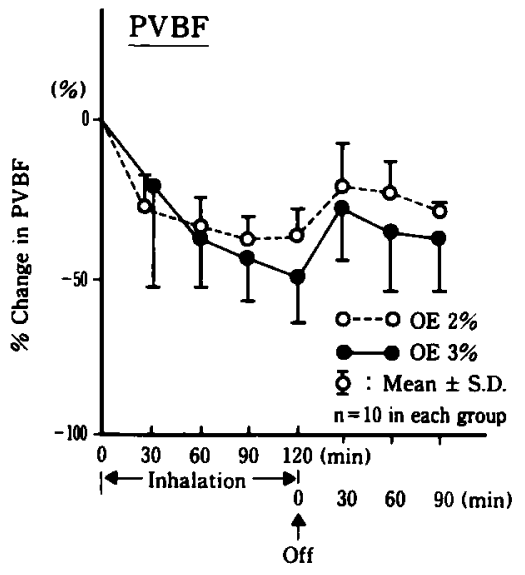

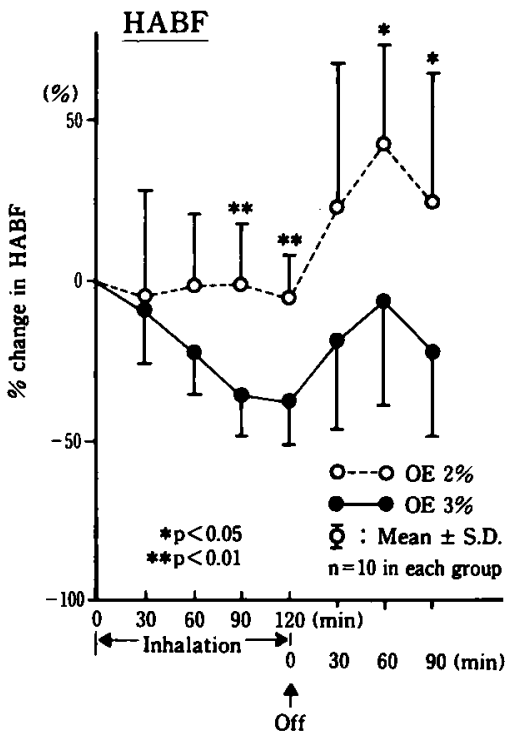

(d)

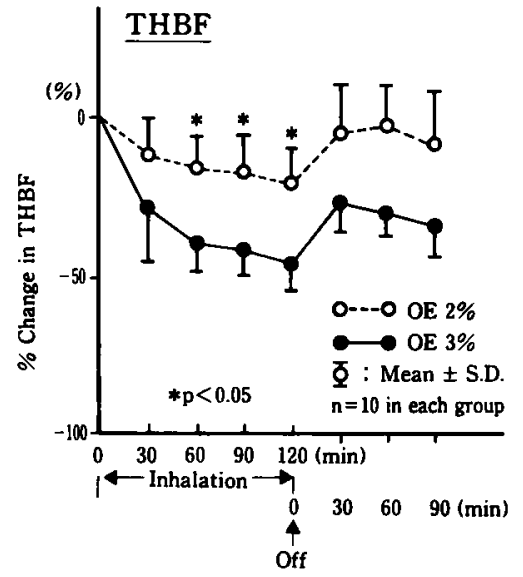

図 5 エンフルレン吸入時および吸入中止後の肝血流状態の経時的変化

エンフルレン吸入時 OE $2 \%$ 群と OE 3 \%群の減少率の間に HTBF は有意差を認めたが, PVBF は有意差を認めなかっだ

HTBF : 肝組織血流量, HABF : 肝動脈血流量, PVBF：門脈血流量, THBF：総肝血流量

值の $18 \%$ 增加したが，以後减少し吸入中止 90 分 後には対照値より $2 \%$ 減少した. OE $3 \%$ 群は, エンフルレン吸入 30 分後には对照値の $26 \%$ 減少 し，以後漸隇し120分後には44\%隇少した。吸 入中止 90 分後には对照値の $23 \%$ の減少を認め た.
$\mathrm{HABF}$ は, 表 1 および図 5 (b)のごとく $\mathrm{OE}$ $2 \%$ 群はエンフルレン吸入中は, 対照值の 5 $7 \%$ 减少し，吸入中止後には対照値の $20 ４ 0 \%$ 増加が認められた. OE $3 \%$ 群は，エンフルレ ン吸入 30 分後に対照值の $10 \%$ 减少し，以後漸減 し 120 分後には $40 \%$ 減少した. 吸入中止後 60 分 
表 2 エンフルレン吸入時および吸入中止後の各血管抵抗値の測定結果

\begin{tabular}{|c|c|c|c|c|c|c|c|c|c|}
\hline & \multirow[b]{2}{*}{ Control } & \multicolumn{4}{|c|}{ Enflurane inhalation } & \multicolumn{3}{|c|}{ Post inhalation } \\
\hline & & & 30 & 60 & 90 & 120 & 30 & 60 & $90(\mathrm{~min})$ \\
\hline SVR & $\begin{array}{l}\text { OE 2\% } \\
\text { OE 3\% }\end{array}$ & $\begin{array}{c}4392.0 \pm 1054.4 \\
3935.2 \pm 1366.4 \\
\text { NS }\end{array}$ & $\begin{array}{c}15.5 \pm 28.2(-1 \\
-33.9 \pm 18.3(H) \\
p<0.01\end{array}$ & $\begin{array}{c}-3.5 \pm 14.8(-) \\
-26.1 \pm 17.2(H) \\
p<0.05\end{array}$ & $\begin{aligned} 21.8 \pm 18.4(t) \\
-25.2 \pm 17.0(t) \\
p<0.01\end{aligned}$ & $\begin{array}{c}30.9 \pm 20.7(t) \\
-11.9 \pm 27.7(-1) \\
p<0.05\end{array}$ & $\begin{array}{c}72.6 \pm 24.5(+) \\
35.7 \pm 47.3(+) \\
\text { NS }\end{array}$ & $\begin{array}{l}74.4 \pm 22.8(t) \\
67.2 \pm 70.21+1 \\
\text { NS }\end{array}$ & $\begin{array}{c}83.9 \pm 35.7(H) \\
87.2 \pm 79.0(H) \\
\text { NS }\end{array}$ \\
\hline MVR & $\begin{array}{l}\text { OE } 2 \% \\
\text { OE } 3 \%\end{array}$ & $\begin{array}{c}29080 \pm 5084 \\
28712 \pm 8200 \\
\text { NS }\end{array}$ & $\begin{array}{c}11.6 \pm 26.7(-) \\
-30.3 \pm 43.1(-) \\
\text { NS }\end{array}$ & $\begin{array}{c}-0.3 \pm 29.2(-) \\
-28.0 \pm 32.2(+1) \\
\text { NS }\end{array}$ & $\begin{array}{l}4.6 \pm 23.04-1 \\
-20.9 \pm 31.5(-) \\
\text { NS }\end{array}$ & $\begin{array}{c}16.0 \pm 25.4(-) \\
2.0 \pm 38.4(-) \\
\text { NS }\end{array}$ & $\begin{array}{c}43.2 \pm 38.5(t) \\
49.9 \pm 51.5(t) \\
\text { NS }\end{array}$ & $\begin{array}{c}54.4 \pm 29.3(*) \\
62.0 \pm 38.3(*) \\
\text { NS }\end{array}$ & $\begin{array}{c}73.0 \pm 41.3(+) \\
90.3 \pm 48.4(+) \\
\text { NS }\end{array}$ \\
\hline HAVR & $\begin{array}{l}\text { OE } 2 \% \\
\text { OE } 3 \%\end{array}$ & $\begin{array}{c}102256 \pm 30560 \\
106480 \pm 34080 \\
\text { NS }\end{array}$ & $\begin{array}{c}-33.4 \pm 34.9(t) \\
-55.7 \pm 14.5(t) \\
\text { NS }\end{array}$ & $\begin{array}{c}-39.6 \pm 15.9(H) \\
-51.1 \pm 15.3(H) \\
\text { NS }\end{array}$ & $\begin{array}{c}-38.2 \pm 10.8(t) \\
-45.8 \pm 17.9(t) \\
\text { NS }\end{array}$ & $\begin{array}{c}-30.0 \pm 9.9(t) \\
-36.4 \pm 19.9(t) \\
\text { NS }\end{array}$ & $\begin{array}{c}-1.2 \pm 49.7(-) \\
35.0 \pm 70.1(-) \\
\text { NS }\end{array}$ & $\begin{array}{c}-17.6 \pm 50.3(-) \\
30.8 \pm 44.5(-) \\
\text { NS }\end{array}$ & $\begin{array}{c}11.0 \pm 61.4(-) \\
33.0 \pm 62.1(-) \\
\text { NS }\end{array}$ \\
\hline
\end{tabular}

各パラメーターの数值は，対照のみ実測值を示し他は対照值を基準としたパーセント变化率を示す。 各群ともに $\mathrm{n}=10$ で数値は，平均值士SDを示す，SVR：全末梢血管抵抗，MVR：腸間膜血管抵抗， HAVR：肝動脈血管抵抗.

各測定項目の対照值の単位は $\mathrm{dyu} \cdot \mathrm{sec} \cdot \mathrm{cm}^{-5}$ である。

(一)：有意差無し, (+)：p<0.05, (++)：p<0.01，は対照值に対する比較である.

NS : 有意差無し, p < $0.05, p<0.01$ は群間比较である.

(a)

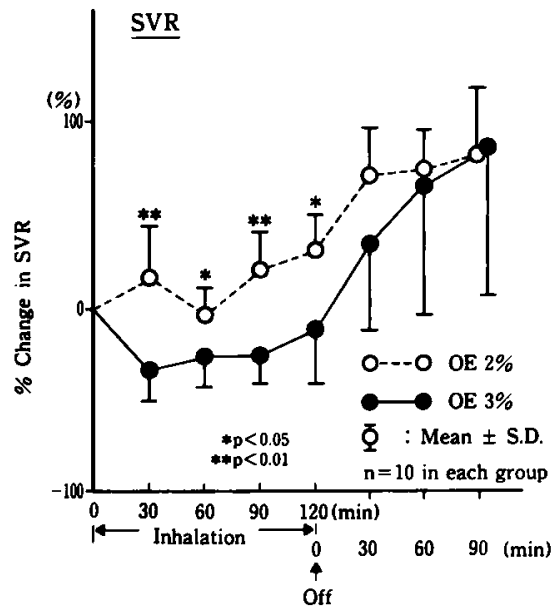

(b)

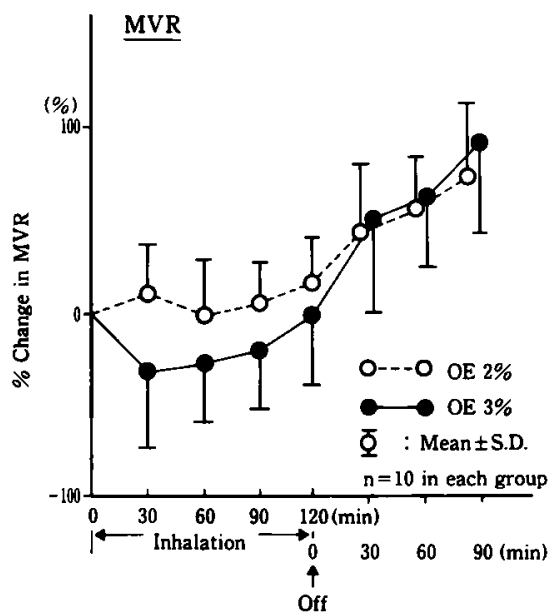

図 6 エンフルレン吸入時および吸入中止後の全末梢血管抵抗(SVR)および腸間膜血管抵抗(MVR)の経時的 変化

エンフルレン吸入中 OE $2 \%$ 群とOE $3 \%$ 群の間の SVR は有意差を認めた. 全経過を通じて SVR と MVR は同様の変化を示すことが認められた.

には対照値の $10 \%$ 減少を示したが，以後再び漸 滅し90分後には24\%減少した。

PVBF は，表 1 および図 5 (c)のごとく OE $2 \%$ 群はエンフルレン吸入30分後には対照値の 28 減少し，その後漸隇して 120 分後には $48 \%$ 减
少した．吸入中止 30 分後には対照値の $22 \%$ 減少 し，以後再び減少の傾向を示した，OE $3 \%$ 群 は，エンフルレン吸入 30 分後には対照值の $22 \%$ 減少し，以後漸减し120分で50\%の減少を認め た. 吸入中止後は，30分後には対照値の $29 \%$ 減 
1510

少まで回復した後, 再び渐減した。

THBF は，表 1 および図 5 (d)のごとく $\mathrm{OE}$ $2 \%$ 群は, 吸入 30 分後には対照値の $16 \%$ 減少し, その後渐隇し120分後には $28 \%$ 減少した。吸入 中止60分後には THBF は対照值の $4 \%$ 減少ま で回復し，以後堿少し 90 分後に $14 \%$ の減少と なった. OE $3 \%$ 群は吸入30分後に対照值の $23 \%$ 減少し，以後漸隇し120分後には対照值の $47 \%$ の減少を認めた．吸入中止後30分には対照 值の $21 \%$ 減少まで回復したが以後減少し90分後 に33\%の隇少を示した.

5. SVR MVR およびHAVR の経時的変 化

SVR は,表 2 および図6(a)のごとくOE $2 \%$ 群は吸入 120 分後には対照值の $31 \%$ 増加し，吸 入中止後にはさらに増加し 90 分後対照値の $84 \%$ 增加した. OE $3 \%$ 群は吸入 30 分後对照値の $34 \%$ 減少したが, 吸入中止後90分後には対照值 に比し増加し，対照值の87\%の増加を示した。

MVR は，表 2 および図 6 (b)のごとく OE $2 \%$ 群はエンフルレン吸入 120 分後対照值の $16 \%$ 增加し，吸入中止後90分で対照値の $73 \%$ 增 加した，OE 3\%群は吸入30分後対照値の30\% 减少したが，吸入中止 90 分後には対照値の $90 \%$ 増加した。

HAVRは, 表 2 のごとく OE $2 \%$ 群は吸入 中, 対照值の $30 \sim 40 \%$ 減少し, 吸入中止後 60 分 で18\%減少となり，以後增加し吸入中止後 90 分 で11\%の増加となった。 OE 3\%群は吸入30分 後対照值の $56 \%$ 隇少し, 以後增加し 120 分後に は36\%の減少を示した。吸入中止90分後には対 照値の $33 \%$ の増加を認めた.

6. 肝静脈血酸素飽和度の経時的变化

表 1 のごとく OE $2 \%$ 群, OE $3 \%$ 群はとも にエンフルレン吸入中は低下し，吸入120分後 OE $2 \%$ 群は対照値の $92.3 \%$, OE $3 \%$ 群は $88.8 \%$ となった.エンフルレン吸入中止後には， 酸素飽和度は上昇し吸入中止 90 分後で $\mathrm{OE}$ $2 \%$ 群は对照値の $98.1 \%$, OE 3\%群は95.4\% となった。

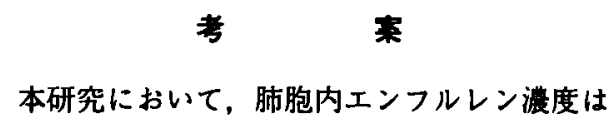

表 1 および図 2，また動脈血中エンフルレン浱 度は表 1 および図 3 に見られるごとく，OE $2 \%$ 群は吸入開始後 90 分, OE $3 \%$ 群は吸入開 始後60分にはエンフルレンの取り込みは，ほほ 平得状態になることが明らかになった。また， OE $2 \%$ 群およびOE $3 \%$ 群の吸入開始後 120 分での肺胞内エンフルレン浱度は，Egar ら6) のエンフルレンの犬における研究結果（1 $\mathrm{MAC}=2.2 \%$ ）をもとに換算すると，それぞ れ0.73 MAC および1.10 MACに相当した.

動脈血中エンフルレン浱度に関しては， Hughes ら 2) は平衡法で $1 \%$ ，1.5\%，2\%をそ れぞれ30分吸入させた後の血中濃度が $29.4 \mathrm{mg}$

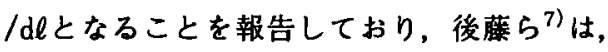
抽出法で $0.35 \% ， 1 \% ， 1.75 \%$ ，それぞれ， 30分吸入させた後の血中港度が，1\%吸入で約 $14 \mathrm{mg} / \mathrm{d} \ell, 1.75 \%$ 吸入で約 $22.5 \mathrm{mg} / \mathrm{d} \ell$ となること を報告している. 本研究結果においても $2 \%$ を 30 分間吸入で $26.1 \mathrm{mg} / \mathrm{d} \ell, 90$ 分間吸入で $29.5 \mathrm{mg}$ $/ \mathrm{d} \ell の$ 值が得られ, 前者らの結果とほほ一致し た.

エンフルレン吸入時における全身循環動態の 変化は, Andreen 5 ${ }^{1)}$ は, $1 \mathrm{MAC}$ GOE 麻㜞 吸入開始開始50分後に MAP, CI, SVR はそ れぞれ 46\%，35\%，19\%隇少し，SVRが対照 值より有意に隇少したと報告している. Hughes ら $^{2)}$ は, NOE 麻酔でエンフルレンを 1 ， $1.5 ， 2 ， 3 \%$ と順に 30 分ずつ吸入させ， $2 \%$ 吸入時において MAP, CI, SVR は $56 \%, 34 \%$, $36 \%$ 減少し, $3 \%$ 吸入では各々 $76 \%, 49 \%, 51 \%$ 滅少しSVRは $2 \%$ および $3 \%$ 吸入のいずれも 対照値より有意に減少したと報告している.

本研究においても OE $2 \%$ 群は, エンフル レン吸入開始後60分，120分で MAP は，対照 值の $43.2 \%, 39.9 \%, \mathrm{CI}$ は $37.5 \%, 47.5 \%$ 減 少し対照に比して有意の減少を示した。 $\mathrm{OE}$ $3 \%$ 群は，吸入開始後60分および 120 分で, MAPは对照値の $62.4 \%, 62.0 \%$, CI $48.1 \%$, $55.5 \%$ 隇少し,对照に比し有意の減少を示した. また, MAPおよび CI は吸入開始60分以後 OE $2 \%$ 群に対して OE $3 \%$ 群は有意の隇少が 認められた。この結果は Andreen, Hughesの 結果とほほ一致していた。 
本研究においてSVRは，OE $2 \%$ 群では吸 入開始 120 分後対照値に対し $30.9 \%$ と有意な增 加を示し, OE 3 \%群は対照值に対し $12 \%$ の減 少が認められた。吸入中，OE $2 \%$ 群に対し OE $3 \%$ 群のSVR が有意に減少したことは， OE $2 \%$ 群では, MAP と CI は同程度 (約 $45 \%$ ) 隇少するが, OE $3 \%$ 群では MAP の減少が CI の減少より大であったためと考えられる.

肝血流量測定は，電磁流量計に加え，水素が スクリアランス法による肝組織血流量測定法を も併用して行なった. 水素ガスクリアランス法 は，局所血流量を絶対値で求められ，反復測定 が可能であるが, 肝血流は，肝動脈と門脈の二 重支配をうけるため本法の応用には問題が残さ れていた。しかし, 牧野ら ${ }^{8) 9)}$, 黒沢ら ${ }^{10)}$ は, 肝に用いるため理論面から検討し，臨床的にも 応用しうる有用な測定法であると述べており本 研究においても使用した.

エンフルレン吸入時の肝血流量に関して, OE $2 \%$ 群では, エンフルレン吸入開始後60分, 120 分で $\mathrm{HABF}$ は $2.0 \%, 7.4 \%, \mathrm{PVBF}$ は $34.2 \%, 37.7 \%$, HTBF は $13.3 \%, 15.0 \%$ 減 少した. OE $3 \%$ 群では, 吸入開始後60分, 120 分で HABF は23.7\%，39.4\%, PVBF は $37.9 \%, 50.4 \%, \mathrm{HTBF}$ は3.8\%, $44.3 \%$ そ れぞれ減少した，即ち，肝血流量（HABF， PVBF, HTBF) はエンフルレン吸入時 OE $2 \%$ 群の HABF 以外，全て对照值に対して有 意に減少していた.

エンフルレン吸入濃度と肝血流量に関して, Andreen $5^{1)}$ は, $1 \mathrm{MAC}$ GOE 麻酔吸入50分 後に, HABF およびPVBF は，35\%，36\%減 少すると述へでおり, 本研究の OE $3 \%$ 群吸 入時の HABF および PVBF の結果とほほ一 致し、さらに, Hughes ら ${ }^{2)}$ は, NOE 麻酔 (工 ンフルレン $1 \%, 1.5 \%, 2 \%, 3 \%$ 各30分吸入) の場合, PVBF は，各源度で対照值より有意 に減少したが, HABFは，3\%吸入時のみ対 照値より有意に隇少したと報告しており，この 報告も本研究と一致していた。

$\mathrm{HABF}$ とPVBF の和である紷肝血流量 (THBF) と HTBFを比較してみると, 表 1 のごとく，対照值およびエンフルレン吸入中の
各時点における THBF と HTBF の血流量は， 両者の間に大きな開きが認められた。しかし， エンフルレン吸入を開始すると, THBF と HTBF は，隇少し，対照值よりの減少率が OE $2 \%$ 群吸入開始後 120 分にはそれぞれ $27.7 \%$ および $15.0 \%$ ，OE $3 \%$ 群吸入開始後 120分には，それぞれ，46.8\%および44.3\%と

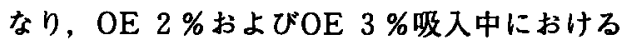
THBF と HTBF の減少率の間には有意差は認 められなく, OE $2 \%$ 以上の麻酔深度では THBF と HTBF は同じ様に減少することが明 らかとなった。

水素ガスクリアランス法は肝の血管の二重支 配, 特に門脈よりの水素ガスの流入という問題 点を有し，電磁流量計はプローべのねじれによ る狭㝛, 血管形状の変化により測定誤差が生じ るという問題点を有するが，雨者の併用により 実際の肝血流状態を反映できるものと考える.

麻酔中の MAP, CI の対照值に対する変化 率と $\mathrm{HABF}, \mathrm{PVBF}, \mathrm{HTBF}$ および THBF の対照值に対する変化率との相関関係をみたも のが図 7 である. MAPに对してPVBF, HTBF および THBF の間には $\mathrm{r}=0.65$ 以上の 正の相関関係が認められた。しかし, MAP と HABF の間には相関関係は認められなかった。 CI に对して PVBF, HTBF およびTHBFの 間には $\mathrm{I}=0.74$ 以上の高い正の相関関係が認め られたが, CI と HABF の間には相関関係は認 められなかった。

$\mathrm{CI}$ とHABF の間の相関関係は, OE $2 \%$ 群

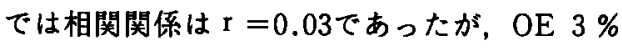
群では $\mathrm{r}=0.60$ となり吸入濃度が上昇するほど $\mathrm{CI}$ と HABF の間に相関関係が生じてくること が認められた。

CIおよびMAPに対してTHBF および HTBFの間に高い正の相関関係が認められた ことは，肝血流量のうち PVBF と HABFの 比が $3: 1$ と PVBF の方が多いため, 森酔中 CI と PVBF が特に高い正の相関関係をもつも のと考えられる. また，OE $2 \%$ 群において HABF がMAP およびCI が低下しても，ほと んど変化しなかったことは，Hanson ら ${ }^{11)}$ が述 べているように, PVBF の增減により，肝動 

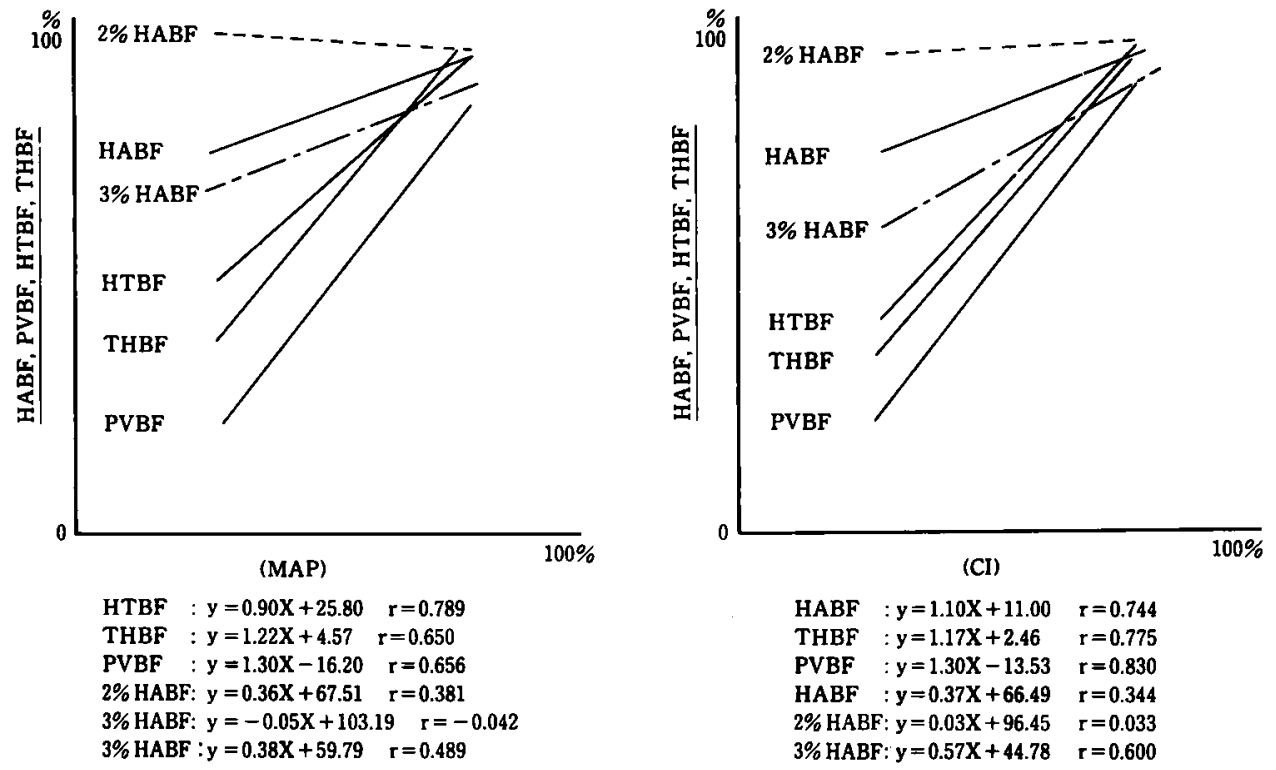

図 7 エンフルレン吸入中の MAP, CI と HABF, PVBF, HTBF およびTHBF の相関関倸

MAP と PVBF, HTBF, THBF は良い相関を示した。また，CI と PVBF, HTBF，THBF は高い 相関を示した.

脈流入部の血管平滑筋を調節して HABF を増 減させる作用が麻酔が浅いため，いまだ残って いるものと考えられる. しかし，OE $3 \%$ 群即 ち $1 \mathrm{MAC}$ 以上の吸入滣度においては，血管平 滑筋の血流調節作用を抑制して CI と $\mathrm{HABF}$ に相関関係が生してくるものと推定された。

MVR とSVRに関しては，表 2 および図 6 のごとく吸入開始後60分，120分において OE $2 \%$ 群の場合, SVR $3.5 \%, 30.9 \%$ 增加, MVR は0.3\%減少, $16.0 \%$ 増加した. OE 3\% 群の場合, SVR は26.1\%, $11.9 \%$ 減少, MVR は28.0\%減少, $2.0 \%$ 增加した. エンフルレン 吸入中はSVR と MVR は同様の変化を示し, 全身の血流分布異常は少ないと考えられた。

エンフルレン吸入中止後の全身循環動態の変 化は, MAP は OE $2 \%$ 群の場合吸入中止 30 分 後には对照値より有意に增加したＯE $3 \%$ 群 の場合, 30分後に対照値に比し有意差のない值 まで回復し，60以降対照值に比し有意に增加し た. CIは OE $2 \%$ 群, OE $3 \%$ 群ともに，麻 酔中止後90分まで対照值に比し $30 \%$ 減少の值ま
でしか回復しなかった. SVRは，OE $2 \%$ 群 は吸入中止後70－84\%の有意な増加，OE 3\% 群は吸入中止後30分までは対照値に比し有意差 はなかったが，それ以後有意な増加を認めた。 以上の現象は, OE $2 \%$ 群では吸入中止後 30 分, OE $3 \%$ 群で吸入中此後60分までに，肺胞内麻 酔薬浱度, 動脈血中麻酔薬濃度が急速に減少し, 麻䣲の敩醒にともないカテコールアミンの分泌 增加が起こり MAP，SVRの増加をもたらし たが心収縮力は，手術および麻酔の影響のため 対照値まで回復しなかったと考えられる。

エンフルレン吸入中止後の肝血流に関して HABF は, OE $2 \%$ 群, OE $3 \%$ 群ともに吸入 中止30分以後，対照值と有意差のない值に回復 した. PVBFは, OE $2 \%$ 群は吸入中止 30 分 以降対照値に比して $22 \sim 30 \%$ 減少, OE $3 \%$ 群 は29 40\%減少した。すなわち，エンフルレン 麻酔後は少なくとも30分まで肝血流の減少が起 こっていることに注意すべきである.

エンフルレン吸入中止後の HAVR は, 対照 に比し有意差なく，SVRおよびMVR は対照 
に比し有意な増加を認め, SVR とMVRは同 様な増加を認めた。

以上のことより，肝血流動態に関しては，エ ンフルレン吸入中, 門脈血流量は心拍出量の減 少に伴い減少するが、肝動脈血流量は OE $2 \%$ 群では保持され，OE 3 \%群では心拍出量減少 に伴い減少した。しかし，この減少本は門脈血 流量の減少率に此べ軽度であり，さらに HAVR はSVR, MVR に比し小さく, 肝静脈 酸素飽和度も, OE $2 \%$ 群, OE $3 \%$ 群でエン フルレン吸入 120 分後に $92.3 \%, 88.8 \%$ と高く, $1 \mathrm{MAC}$ までのエンフルレン麻醉では肝の血流 動態は保たれて, 肝における酸素の需給バラン スが良く維持されるものと考えられる.

\section{桔語}

雑種成犬20頭を用いてエンフルレン吸入中 (酸素・エンフルレン麻䣲 $2 \%$ および $3 \%$ ：以 下OE $2 \%$ 群, OE $3 \%$ 群) およびエンフルレ ン吸入中止後における全身循環動態と肝循環動 驡の検討を行なった.

全身循環動態に関して，エンフルレン吸入中 OE $2 \%$ 群は，MAP と CI とは減少率が同程 度であったが, OE 3 \%群は, MAP の隇少率 がCIの堿少率より大きかった～エンフルレン 吸入中止後は, OE $2 \%$ 群, OE $3 \%$ 群ともに MAPは速やかに対照の状態に復したが，CI は両群ともに吸入中止後30分で対照値の70\%に 回復し，以後吸入中止後 90 分まで同程度であっ た.

肝循環動態に関して，エンフルレン吸入開始 後120分において，OE $2 \%$ 群では HABF が对 照に比し7.4\%減少, PVBF は37.7\%減少した。 OE $3 \%$ 群では HABF, PVBF は対照に比し, それぞれ，39.4\%，50.4\%隇少した. エンフル レン吸入中には, PVBF の滅少率に比し HABF の減少率が軽度であった. エンフルレ ン吸入中止後 OE $2 \%$ 群の HABF は対照に比 し20〜34\%增加, PVBF は22〜37\%減少した。
OE $3 \%$ 群ではHABF は対照に比し8〜25\%減 少, PVBF は29〜40\%減少した。

血管抵抗値に関して，エンフルレン吸入中 SVR とVRは，OE $2 \%$ 群および OE $3 \%$ 群ともに同様の変化を示し，全身の血流分布異 常は少ないと考えられる。吸入中止後において もSVRとMVRは,OE $2 \%$ 群および OE $3 \%$ 群ともに，それぞれ対照より有意に増加し同様 の変化を示した. HAVRは，エンフルレン吸 入中OE $2 \%$ 群および OE $3 \%$ 群ともにSVR, MVRより低値をとり対照に比し有意な減少を 認めた. エンフルレン吸入中止後は，对照值と 有意差はなかった。

$\mathrm{CI}$ の変化率と PVBF および HABF の変化 率の相関関係をみると，CIに対してPVBF は $\mathbf{r}=0.83$ という高い正の相関関係が認められた が, CI と HABF の間の相関関係は, OE $2 \%$ 群は $\mathrm{r}=0.03$ あったが, OE $3 \%$ 群は $\mathrm{r}=$ 0.60 となり, 吸入㬊度が増加するほど相関関係 が生しることが認められた。

以上の結果よりエンフルレン吸入中は，心拍 出量の減少に伴い, 門脈血流量は隇少したが OE $2 \%$ 群では肝動脈血流量は保持され，OE $3 \%$ 群即ち約 $1 \mathrm{MAC}$ 麻醉では, 心拍出量の 減少と肝動脈血流量の減少との間に正の相関が 生じた。しかし,この滅少率は門脈血流量の減 少率よりも軽度であり，さらに HAVRは, SVR およびMVRに比し小さかった。

エンフルレン麻酔は, OE $2 \%$ 群抢よび OE $3 \%$ 群ともにSVR, MVRを同様に変化させ るため, 全身の血流分布異常は少ないと考えら れ, 肝動脈血流量の減少は門脈血流量隇少に比 し軽度であることも明らかとなった。

本稿の要旨は，第33回日本麻醉学会（京都・1986） において発表した，稿を終えるにあたり，ご指導 ご校閲をいただいた岡山大学医学部麻酔・萩生学 教室，小坂二度見教授に深謝するとともに，同教 室山田輝夫博士に謝意を表します。

文
献

1. Irestedt $L$ and Andreen $M$ : Effects of enfluranne on haemodynamic and oxygen consumption in the dog with special reference to the liver and preportal tissues. Acta Anaesth Scand (1979) 23, 13-26. 
2. Hughes RL, Campbell D and Fitch W: Effect of enflurance and halothane on liver blood flow and oxygen consumption in the grayhound. Br. J. Anaesth (1980) 52, 1079-1086.

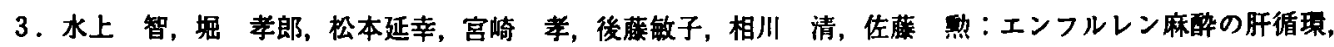
肝代謝に及はす影響。麻䣲（1984）33，1213-1217。

4. 山田燂夫，片山 浩，小坂 誠，飯島義雄，瀨戸甲藏，板野義太郎，西本雅彦，塩飽善友，小坂二度見： ガスクロマトグラフィーによる血中麻醉薬㵊度の測定に関する研究 (II)．麻醉（1982）31，1114-1124.

5. Dubois EF: Basal Metabolism in Health and Disease. Lea and Febiger, Philadelphia (1936).

6. Eger $E$, Miller $S$ and Stevens $W$ : Anesthetic potencies of sulfer hexafluoride, carbon tetrafluoride, chloform and Ethrane in dogs. Anesthesiology (1969) 30, 129-135.

7. 後蕴康之, 久保田宗宏, 高野光子, 古川幸道：エスレン麻醉時の血行力学的研究．麻醉（1974）23，611 -616 .

8. 牧野隆光, 石田 博, 常岡健二，大橋和史：水素ガスクリマランス法の肝組織血流量測定への応用一理論 面からの検討. 病態生理 (1983) 2，1049-1052.

9. 牧野隆光，坂本文夫，幸坂宣俊，金沢秀典，堂園孝史，古川陽太郎，石田 博，黒田 殕，常岡健二：水 素ガスクリアランス法による肝組穖血流測定法とその臨床応用. Prog Digestive Endosco（1982）21, $125-129$.

10. 黒沢和平，林 紀夫，笠原彰紀，目連晴哉，佐々木裕，佐藤信紘，鎌田武信，阿部 裕，莉原丈二 : 水素 クリアランスによる肝血流測定の基砹的検討. 肝荿（1983）24，728-732.

11. Hanson $K \mathrm{M}$ and Johnson $\mathrm{P} C$ : Local control of hepatic arterial and portal venous flow in the dog. Am J Physiol (1966) 211, 712-720. 


\section{Effect of Enflurane Anesthesia on the Systemic and Hepatic Circulation in the Dog Masahiro TANIGUCHI \\ Department of Anesthesiology and Resuscitology, Okayama University Medical School, Okayama \\ (Director : Prof. F. Kosaka)}

The systemic and hepatic circulation of 20 adult mongrel dogs was examined during and after inhalation of $2 \%(\mathrm{OE} 2 \%)$ and $3 \%(\mathrm{OE} 3 \%)$ enflurane in oxygen.

A high correlation ( $r=0.83$ ) was noted between $\mathrm{CI}$ and PVBF. A correlation between CI and $\mathrm{HABF}$ was recognized at the higher concentration of the anesthetic : $r=0.03$ in the $0 E 2 \%$ group, and $r=0.60$ in the $0 E 3 \%$ group. The systemic vascular resistance (SVR) and mesenteric vascular resistance (MVR) changed similarly in the OE2\% and OE3\% groups, and the disturbance of the systemic blood flow distribution was considered slight. SVR and MVR increased similarly to levels significantly above the control levels after termination of enflurane inhalation in both groups. The hepatic arterial vascular resistance (HAVR) during inhalation was lower than either SVR or MVR, and was sighificantly lower than the control level in both groups. However, after the inhalation was terminated, there no longer was a significant difference between the experimental and control HAVR. Since SVR and MVR changed similarly at both concentrations of enflurane, disturbance of the systemic blood flow distribution was thought to be small. It was clear that the decrease in HABF was less than the decrease in PVBF. 